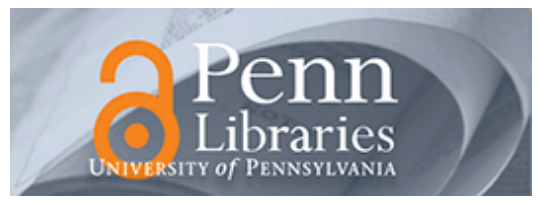

University of Pennsylvania

ScholarlyCommons

Management Papers

Wharton Faculty Research

2014

Homebuilders, Affiliated Financing Arms, and the Mortgage Crisis

Sumit Agarwal

Follow this and additional works at: https://repository.upenn.edu/mgmt_papers

Part of the Management Sciences and Quantitative Methods Commons

Recommended Citation

Agarwal, S. (2014). Homebuilders, Affiliated Financing Arms, and the Mortgage Crisis. Economic Perspectives, 38 (2), 38-51. Retrieved from https://repository.upenn.edu/mgmt_papers/218

This paper is posted at ScholarlyCommons. https://repository.upenn.edu/mgmt_papers/218

For more information, please contact repository@pobox.upenn.edu. 


\title{
Homebuilders, Affiliated Financing Arms, and the Mortgage Crisis
}

\author{
Abstract \\ The authors' findings indicate that homebuilder financing affiliates do make loans to observably riskier \\ borrowers, but the loans made by homebuilders have lower delinquency rates than those made by \\ unaffiliated lenders, even when loan and borrower characteristics are held constant. \\ Disciplines \\ Management Sciences and Quantitative Methods
}




\title{
Homebuilders, affiliated financing arms, and the mortgage crisis
}

\author{
Sumit Agarwal, Gene Amromin, Claudine Gartenberg, Anna Paulson, and Sriram Villupuram
}

\section{Introduction and summary}

Nearly a third of all families purchasing new homes in 2006 obtained a mortgage from a financing company owned by or affiliated with a large homebuilder (see figure 1$).{ }^{1}$ Eighty percent of these loans were made by financing companies associated with one of the ten largest homebuilders in the country. ${ }^{2}$ In addition to accounting for a large share of new home sales and financing, homebuilders were particularly active in areas of the country where the subprime crisis was most acute (Arizona, California, Florida, and Nevada). As well as being important simply because of the number of loans that they underwrite, homebuilder financing arms are interesting because their incentives differ from those of unaffiliated lenders. ${ }^{3}$ Press accounts of homebuilder lending practices have focused on their incentive to sell homes and their purported willingness to extend unconventional mortgage products to borrowers with less-than-stellar credit histories. ${ }^{4}$ These factors have led to accusations that homebuilders contributed to the formation of the housing bubble and the ensuing foreclosure crisis. However, despite playing a potentially important role in explaining house price trends and mortgage defaults, homebuilder mortgage lending has received little research attention to date. ${ }^{5}$

At first glance, the allegations of the nefarious role played by the homebuilders in the crisis are consistent with academic research on the behavior of lenders affiliated with a company that produced the good that is being financed. From an intuitive viewpoint, homebuilder financing arms may behave differently because their corporate parent profits from both the sale of the house and its financing and continues to lose money the longer the home stays in inventory. Consequently, such lenders have a strong motivation to find financing terms that will lead to a sale. This incentive may in turn lead to less screening of borrowers and to mortgage terms that get the deal done but may not be sustainable for the borrower. As the pace of home purchases slowed in 2006-07 and homebuilders were faced with growing inventories of unsold homes, these incentives may have become even stronger.

This intuition has been evaluated empirically in other (non-housing) markets by a number of studies that looked at credit decisions and subsequent performance of loans made by the affiliated lenders. In particular,

Sumit Agarwal is a professor of economics, finance, and real estate at the National University of Singapore. Gene Amromin is a senior financial economist and economic advisor at the Federal Reserve Bank of Chicago. Claudine Gartenberg is an assistant professor of management at New York University. Anna Paulson is a vice president and the director of financial research at the Federal Reserve Bank of Chicago. Sriram Villupuram is an assistant professor of finance and real estate at Colorado State University. Caitlin Kearns, Rob McMenamin, and Edward Zhong provided outstanding research assistance. The authors thank seminar participants at the Federal Reserve Bank of Chicago.

(C) 2014 Federal Reserve Bank of Chicago

Economic Perspectives is published by the Economic Research Department of the Federal Reserve Bank of Chicago. The views expressed are the authors' and do not necessarily reflect the views of the Federal Reserve Bank of Chicago or the Federal Reserve System.

Charles L. Evans, President; Daniel G. Sullivan, Executive Vice President and Director of Research; Spencer Krane, Senior Vice President and Economic Advisor; David Marshall, Senior Vice President, financial markets group; Daniel Aaronson, Vice President, microeconomic policy research; Jonas D. M. Fisher, Vice President, macroeconomic policy research; Richard Heckinger, Vice President, markets team; Anna L. Paulson, Vice President, finance team; William A. Testa, Vice President, regional programs; Richard D. Porter, Vice President and Economics Editor; Helen Koshy and Han Y. Choi, Editors; Rita Molloy and Julia Baker, Production Editors; Sheila A. Mangler, Editorial Assistant.

Economic Perspectives articles may be reproduced in whole or in part, provided the articles are not reproduced or distributed for commercial gain and provided the source is appropriately credited. Prior written permission must be obtained for any other reproduction, distribution, republication, or creation of derivative works of Economic Perspectives articles. To request permission, please contact Helen Koshy, senior editor, at 312-322-5830 or email Helen.Koshy@chi.frb.org.

ISSN 0164-0682 
Quarterly home purchases and mortgage originations, four-quarter moving average (000s)

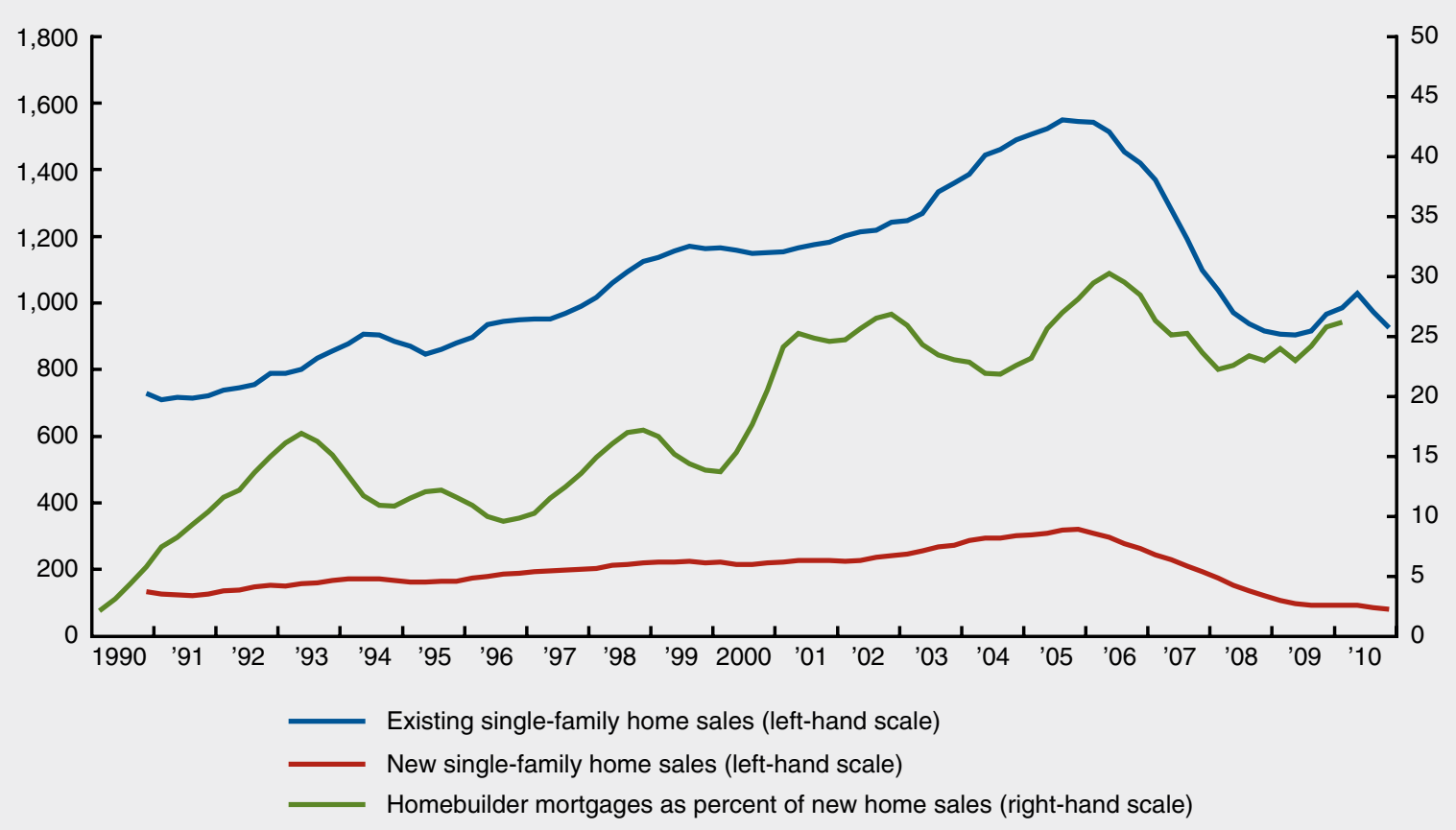

Sources: HMDA (Home Mortgage Disclosure Act) data, U.S. Census Bureau, U.S. Department of Housing and Urban Development, and the National Association of Realtors.

studies that compare bank lending with that of captive finance companies (Carey, Post, and Sharpe, 1998) and of auto lending (Barron, Chong, and Staten, 2008) suggest that affiliated finance companies have a greater incentive to focus on moving inventory into the "sold" column. Both of these papers find evidence that finance companies serve observably riskier borrowers and, in the case of auto loans, that loans by affiliated lenders experience higher default rates. A related literature focuses on the more general case in which some lenders possess superior information about the borrower, which is arguably true in the case of affiliated lenders. For instance, Degryse and Ongena (2005) and Agarwal and Hauswald (2010) evaluate the effects of proximity between lenders and borrowers on credit allocation decisions, with the premise that shorter distances proxy for better information. These papers find that moredistant borrowers pay higher interest rates, which is consistent with the idea of asymmetric information between borrowers and lenders. In this article, we use loan-level data from 2001 to 2008 to investigate the characteristics and default outcomes of home purchase mortgages underwritten by homebuilders, compared with those of mortgages issued by unaffiliated financial institutions. Our findings indicate that homebuilder financing affiliates do make loans to observably riskier borrowers, as one might expect from the literature, and that a greater share of homebuilder loans have risky characteristics (for example, little documentation). Despite these limitations, loans made by homebuilders have lower 12- and 24-month delinquency rates over our full sample period than loans made by unaffiliated lenders, even when loan and borrower characteristics are held constant. While homebuilder loans outperform similar loans made by other lenders throughout the period that we examine, their relative default performance in the near term (12-month) is stronger even among loans originated during the boom-and-bust period that includes 2005 through 2008. Even over a longer 24-month horizon, we find no evidence that homebuilder loans had higher default rates. These findings are surprising, given that industry lending standards were particularly lax in 2005 and 2006 and that homebuilders were burdened by large unsold home inventories in 2007 and 2008.

Our findings thus run counter to the existing work on affiliated lending in auto lending and captive finance companies. They also pose a challenge to explanations of the housing bubble and the foreclosure crisis that assign a central role to homebuilders and their lending 
affiliates. Indeed, since builder-affiliated lenders were able to lend to riskier borrowers and still deliver superior default performance, perhaps some aspects of their lending practices should be emulated as policymakers aim to mitigate defaults while maintaining access to credit for a wide cross section of home buyers.

Although our study lacks the necessary data to determine specific reasons behind homebuilder ability to achieve lower default rates, we offer some potential explanations, most of which rely on the special nature of housing markets. They include: 1) a superior ability of homebuilder-affiliated lenders to procure information about borrowers and the quality of housing collateral; 2) stronger incentives within affiliated lenders for risk management in loan underwriting that may stem both from their reliance on capital market funding and the multistage nature of homebuilding projects; 3 ) the auxiliary provision of financial education and coaching to borrowers; and 4) borrower self-selection associated with a sometimes lengthy period between down payment and taking possession of a finished home.

The next section of the article provides a description of the data. This is followed by a univariate comparison of the borrower and loan characteristics, as well as the delinquency experience of homebuilder versus non-homebuilder loans over the 2001-08 period. Then we present the associated multivariate analysis, which incorporates macroeconomic factors as well as microdata on borrower and loan characteristics. We examine the potential role of changes in the underwriting process and homebuilder incentives during two distinct periods: 2001-04 (the initial buildup in housing prices) and 2005-08 (the period when housing prices peaked and then declined sharply). Next, we focus on the relative performance of homebuilder loans within specific mortgage contract categories. Finally, we discuss the results and steps for future work.

\section{Data}

We use two main sources of data for our study: loan-level data furnished by LPS Applied Analytics (LPS) and the public version of the database of home loan applications and originations collected under the Home Mortgage Disclosure Act (HMDA). LPS aggregates data from mortgage-servicing companies that participate in the HOPE NOW Alliance. ${ }^{6}$ The most recent LPS data cover about 30 million mortgages throughout the United States. Our sample covers mortgages originated between 2001 and 2008, which allows us to analyze the loans made during the housing bubble buildup years $2001-04$, as well as the 2005-08 period, during which housing prices peaked and then collapsed. The data include prime and subprime mortgages, as well as loans that are securitized or held on bank balance sheets. In addition to monthly data on loan performance, LPS contains information on key borrower and loan characteristics at origination. Based on a comparison of the LPS and HMDA data, we estimate that the LPS data cover about 60 percent of the prime market each year from 2004 through 2007. Coverage of the subprime market is somewhat smaller, but increases over time, going from just under 30 percent in 2004 to just under 50 percent in 2007 . In addition to monthly data on loan performance status, LPS contains information on key borrower and loan characteristics at origination. This includes the borrower's FICO credit score, the loan amount and interest rate, whether the loan is a fixed or a variable-rate mortgage, the ratio of loan amount to home value (LTV), and whether the loan was intended for home purchase or refinancing. Unfortunately, we do not observe whether borrowers took on additional mortgages in the form of piggyback loans that accompanied the first mortgage, or in the form of second-lien lines of credit or closed-end loans originated at some later point. The outcome variable that we focus on is whether the loan becomes 90 days or more past due in the 12 months following origination. We focus on loan performance during the first 12 and 24 months since mortgage origination rather than a longer period, so that loans made in 2008 can be analyzed in the same way as earlier loans, as our data are complete through the end of 2010.

Because homebuilders do not participate in refinancing markets, we limit our sample to mortgages used for home purchase. We further exclude purchases of non-single-family residences, as well as FHA (Federal Housing Administration) and VA (U.S. Department of Veterans Affairs) mortgages. ${ }^{7}$ The resulting sample consists of about 86,000 mortgages originated by homebuilder-affiliated lenders and 5.2 million mortgages originated by unaffiliated financial institutions between 2001 and 2008.

\section{Homebuilder loans, borrowers, and their mortgage performance}

The first two columns of table 1 compare the geographic distribution of homebuilder lending activity and the attributes of homebuilder borrowers with those of other lenders over the entire sample period. It further contrasts loan characteristics and performance of homebuilder and non-homebuilder loans.

Homebuilder lending appears to have been more concentrated in areas that exhibited high house price growth during the formative years of the bubble and that experienced a collapse in prices in 2006-08. In particular, the four states most commonly associated 
TABLE 1

Homebuilder loans, borrowers, and mortgage performance

The sample includes purchase, conventional, first-lien mortgages for single-family homes.

\begin{tabular}{|c|c|c|c|c|c|c|}
\hline \multirow[b]{2}{*}{ Year of origination } & \multirow{2}{*}{$\begin{array}{c}\begin{array}{c}\text { Builder } \\
\text { affiliates }\end{array} \\
2001-08\end{array}$} & \multirow{2}{*}{$\begin{array}{c}\begin{array}{c}\text { Other } \\
\text { lenders }\end{array} \\
2001-08\end{array}$} & \multicolumn{2}{|c|}{$\begin{array}{c}\text { Builder } \\
\text { affiliates }\end{array}$} & \multicolumn{2}{|c|}{$\begin{array}{l}\text { Other } \\
\text { lenders }\end{array}$} \\
\hline & & & $2001-04$ & $2005-08$ & 2001-04 & 2005-08 \\
\hline Number of loans & 85,767 & $5,234,080$ & 54,487 & 31,280 & $2,559,824$ & $2,674,256$ \\
\hline Bubble state loans (\%) & 0.32 & 0.21 & 0.29 & 0.35 & 0.23 & 0.20 \\
\hline Median FICO score & 720 & 732 & 714 & 730 & 731 & 732 \\
\hline FICO below 620 (\%) & 0.08 & 0.05 & 0.11 & 0.04 & 0.05 & 0.06 \\
\hline FICO below 660 (\%) & 0.21 & 0.15 & 0.25 & 0.13 & 0.15 & 0.16 \\
\hline Median household income (\$) & 76,000 & 78,000 & 71,000 & 88,000 & 74,000 & 83,000 \\
\hline Median home value $(\$)$ & 233,000 & 225,000 & 200,000 & 295,495 & 204,000 & 248,000 \\
\hline Median value-to-income ratio & 3.08 & 3.01 & 2.92 & 3.43 & 2.92 & 3.11 \\
\hline Median mortgage amount (\$) & 179,350 & 173,375 & 157,736 & 224,800 & 158,650 & 189,900 \\
\hline Median loan-to-value (LTV) ratio & 79.59 & 79.79 & 79.78 & 79.20 & 79.89 & 79.70 \\
\hline Fixed-rate mortgages (\%) & 0.71 & 0.73 & 0.74 & 0.65 & 0.74 & 0.71 \\
\hline Adjustable-rate mortgages (\%) & 0.14 & 0.08 & 0.21 & 0.03 & 0.12 & 0.04 \\
\hline Hybrid adjustable-rate mortgages (\%) & 0.03 & 0.05 & 0.01 & 0.07 & 0.04 & 0.06 \\
\hline Non-amortizing mortgages (\%) & 0.12 & 0.15 & 0.04 & 0.25 & 0.10 & 0.19 \\
\hline Prepayment penalties (\%) & 0.13 & 0.09 & 0.17 & 0.07 & 0.10 & 0.08 \\
\hline Less-than-full documentation (\%) & 0.38 & 0.29 & 0.32 & 0.40 & 0.28 & 0.29 \\
\hline 12-month securitization rate & 96.0 & 90.2 & 95.7 & 96.3 & 90.3 & 90.2 \\
\hline 12-month default rate & 1.2 & 1.6 & 0.5 & 2.4 & 0.5 & 2.7 \\
\hline 24-month default rate & 3.9 & 4.4 & 1.0 & 9.0 & 1.5 & 7.2 \\
\hline 12-month default rate $(\mathrm{FICO}<660)$ & 3.3 & 6.4 & 1.4 & 10.3 & 2.3 & 10.0 \\
\hline 24-month default rate $(\mathrm{FICO}<660)$ & 8.1 & 15.0 & 2.7 & 27.4 & 6.0 & 23.1 \\
\hline 12-month default rate $(\mathrm{FICO} \geq 660)$ & 0.6 & 0.8 & 0.2 & 1.2 & 0.2 & 1.3 \\
\hline 24-month default rate $(\mathrm{FICO} \geq 660)$ & 2.8 & 2.5 & 0.4 & 6.6 & 0.7 & 4.2 \\
\hline
\end{tabular}

with the bubble-Arizona, California, Florida, and Nevada - account for about 32 percent of homebuilder lending, but only 21 percent of loans for home purchase by other lender types. Figure 2, which presents a countylevel distribution of the mortgage market share attributed to the affiliated homebuilder lenders, paints a similar picture.

Over the entire sample, the average FICO score of homebuilder borrowers was lower than that of borrowers with loans from non-builders. This difference is due to the higher share of subprime and near-subprime households among those financed by the homebuilders. Among homebuilder borrowers, 21 percent had FICO scores below 660, compared with 15 percent for those who borrowed from other lenders. Loans originated by homebuilders were more likely to contain prepayment penalties.

Relative to other borrowers, those obtaining credit from a builder had similar annual incomes but purchased a somewhat more expensive house. The resulting difference in median ratios of house value to household income (VTI) is both economically and statistically significant - for a given level of income, homebuilder borrowers purchased houses valued at about 2.5 percent more than non-homebuilder borrowers.

There is very little difference in average mortgage values or first-lien loan-to-value (LTV) ratios of homebuilder and non-homebuilder loans. Taken together with values for income and house values, this suggests that homebuilder borrowers took on larger mortgages with lower income bases. The weaker financial footing of homebuilder borrowers is also underscored by their greater reliance on mortgages underwritten on the basis of less-than-full documentation. At least 38 percent of homebuilder loans were based on the borrowers' stated, as opposed to verified, income. Earlier work has shown that stated income loans, on average, overstated household earnings (Jiang, Nelson, and Vytlacil, forthcoming). In addition, homebuilder mortgages were more likely to have adjustable rates or be non-amortizing, 


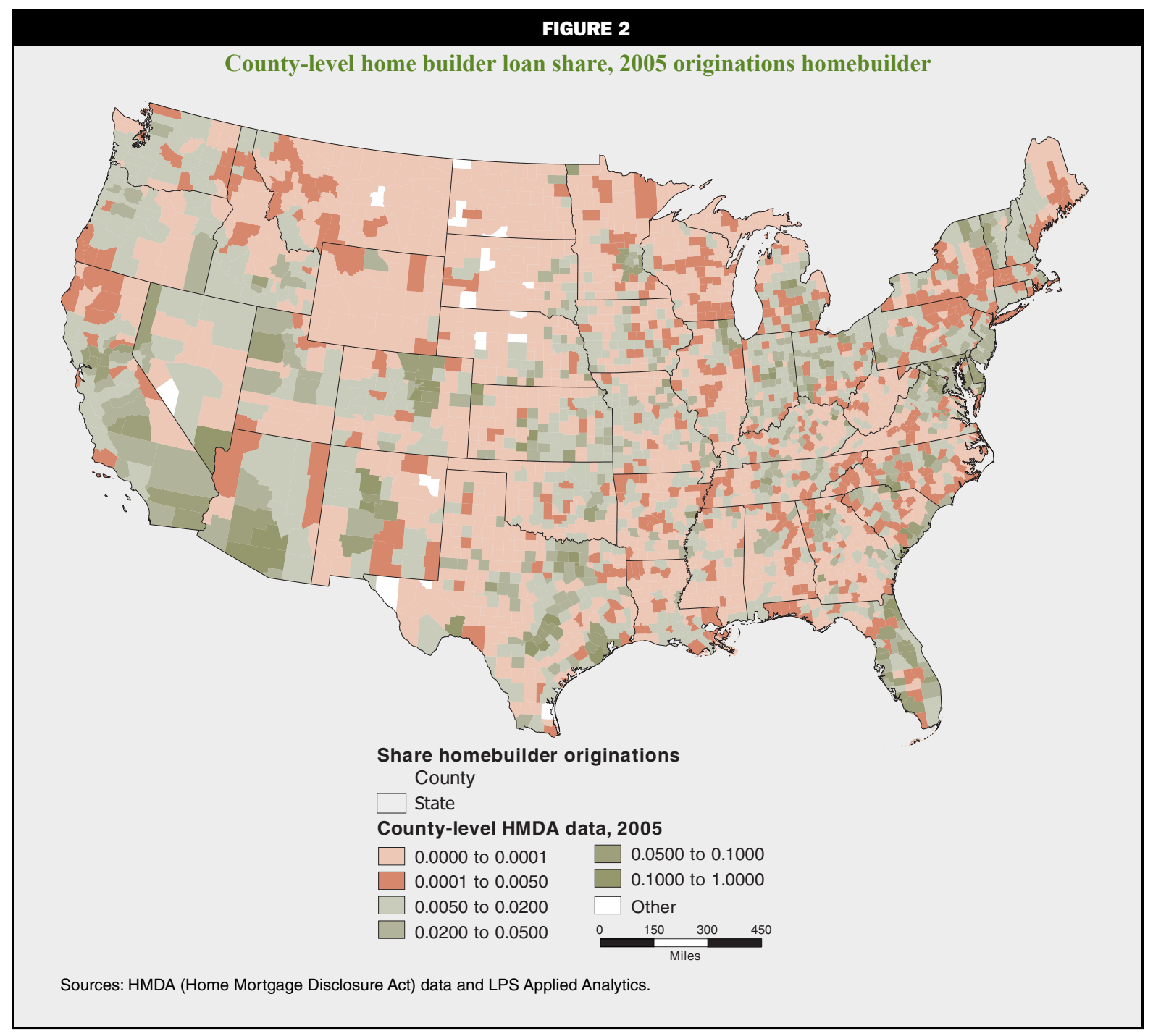

thereby reducing the initial monthly mortgage service flows relative to more traditional fixed-rate loans.

At first glance, this summary is consistent with the common perception that homebuilders offered loans in bubble areas, were willing to lend to less creditworthy buyers who were buying more expensive homes relative to their (stated) incomes, and used loan contracts with riskier features, such as prepayment penalties, adjustable interest rates, and non-amortizing schedules.

However, as evidenced by the comparison of columns 1 and 2 in table 1, homebuilder lending resulted in lower defaults than other types of lending. During the first 12 months following loan origination, borrowers with loans from homebuilders defaulted at a 1.2 percent rate, compared with a 1.6 percent rate among borrowers with non-homebuilder loans. ${ }^{8}$ This difference in loan performance was particularly pronounced among the subset of borrowers with the lowest credit scores (FICO scores below 660), for which homebuilder loans display markedly lower default rates. Among such borrowers, the average 12-month default rate on homebuilder loans originated during 2001-08 is 3.3 percent; the corresponding figure for non-homebuilder loans is 6.4 percent. This difference persists over a 24-month horizon when default rates for homebuilder loans rise to 8.1 percent and for non-homebuilder loans to 15.0 percent. Among more-creditworthy borrowers (FICO scores above 660), homebuilder loans outperform the non-homebuilder loans over the 12-month horizon, but exhibit somewhat higher default rates over the 24-month horizon.

Figure 3 provides some insight into temporal properties of defaults on loans originated by the two types of lenders. For a given vintage of loans (those originated in calendar year 2005), figure 3 plots the monthly series of the fraction of loans that become 90 days or more past due. The early relative performance of 


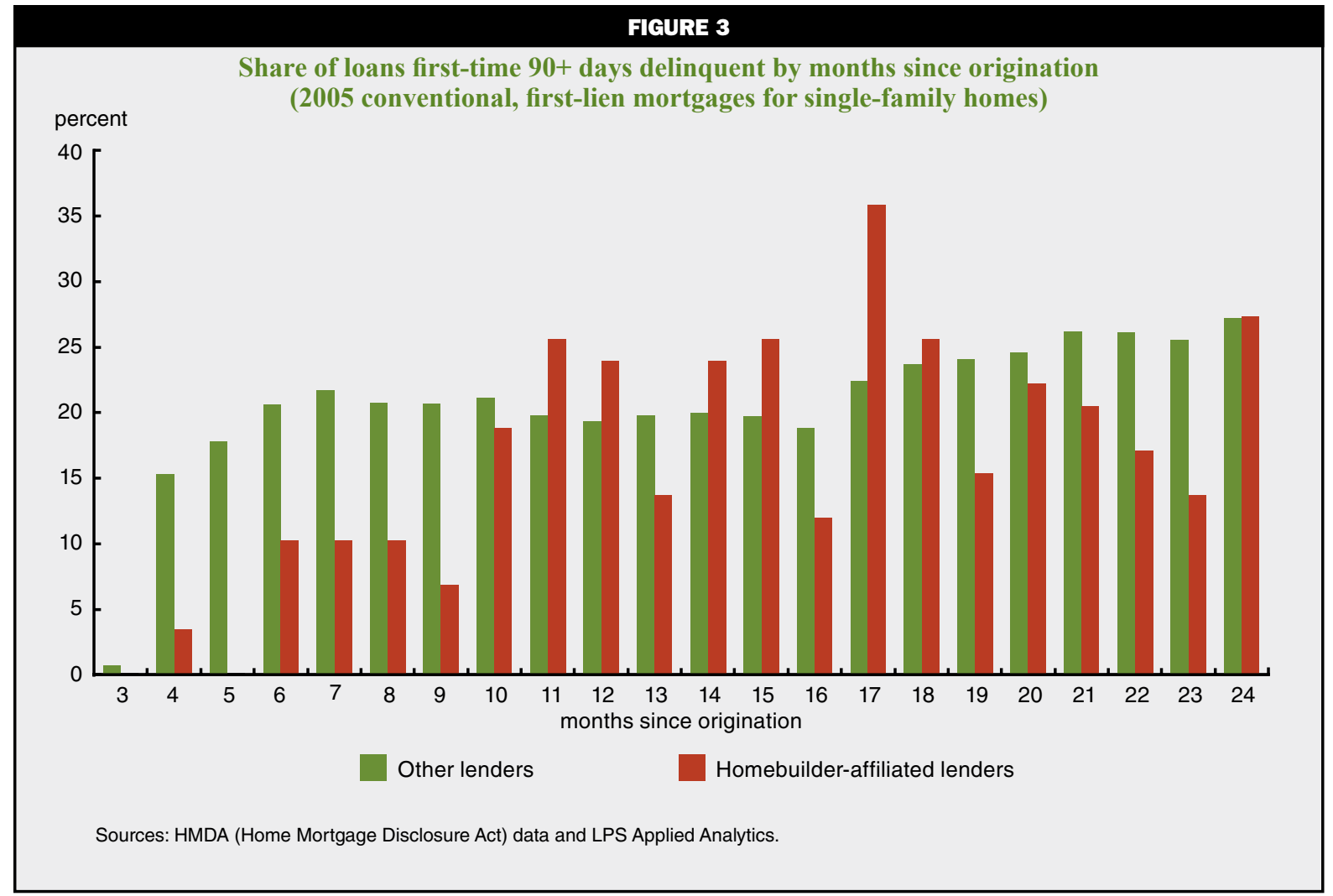

loans originated by homebuilder lenders is particularly striking, as there are very few defaults in the first nine months following origination. Although the monthly default rates of the two lender types converge somewhat over time, the less creditworthy borrowers served by the homebuilders fare better throughout most of the 24-month horizon.

Figure 4 offers a spatial perspective on defaults during the first 12 months for loans originated in 2005. A quick visual inspection suggests that the areas of the country that experienced the highest mortgage default rates in 2006 were not the same ones that had the largest fractions of home purchases financed by homebuilder lending affiliates. ${ }^{9}$

Note that the above analysis focuses on the unconditional default rate and does not take into account the geographic concentration of homebuilder loans in the bubble states or the greater share of loan features (for example, adjustable rates or less-than-full documentation), all of which would tend to make homebuilder default rates higher. Put differently, homebuilders make riskier loans, on average, and these loans have lower defaults than safer loans made by other lenders.

\section{Controlling for characteristics of loans, borrowers, and geography}

The univariate comparisons in the preceding section do not take into account the differences in homebuilder and non-homebuilder loans summarized in table 1 or differences in trends in the relative activity of homebuilders versus other lenders over time. To account for these differences, we estimate a logit model of mortgage default that conditions on location-specific macroeconomic factors, as well as the borrower and loan characteristics described in table $1 .{ }^{10}$ In addition to a set of state dummies and origination year fixed effects, these specifications also include the change in the MSA (metropolitan statistical area) level home price index, the change in the average unemployment rate, and the change in the market interest rate. All of these changes are computed between the quarter of mortgage origination and the earliest of the mortgage default rate or the end of the evaluation horizon (either 12 or 24 months since origination). The model is estimated on loan-level data, and standard errors are clustered at the state level. The difference in conditional default rates between homebuilder- and non-homebuilder-originated loans is captured by an indicator variable for homebuilder mortgages. 


\section{County-level delinquency rates, 2005 originations}

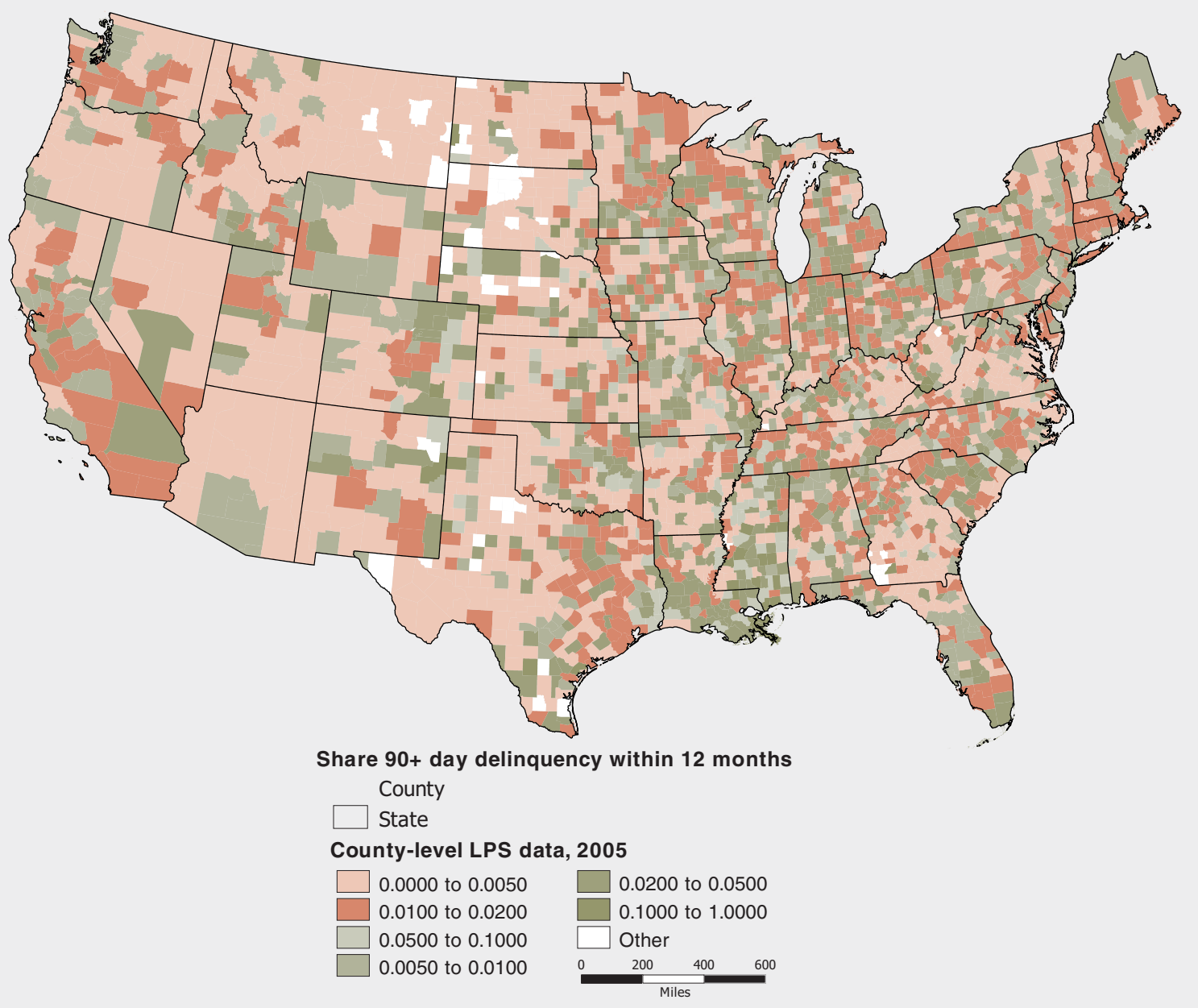

Source: LPS Applied Analytics.

The set of regression results that incorporates these controls is shown in table 2, where the displayed coefficients represent marginal effects measured in percentage points. The first column contains the analysis of mortgage performance over the first 12 months since origination, while the second column shows the results for the 24-month horizon. Both regressions cover the entire sample period from 2001 through the end of 2008. We find that over both horizons, the estimated coefficient on builder-affiliated loans is negative, suggesting lower default rates conditional on a large set of observable factors. These estimates are significant both statistically and economically. The 0.74 percentage point difference in conditional 12-month default rates is very precisely estimated, and it represents a substantial improvement over the baseline default rate of 1.6 percent. Similarly, the 1.24 percentage point difference in column 2 represents a sizable improvement over the baseline 24-month default rate of 4.5 percent.

Among the macroeconomic control variables, the concurrent change in the metropolitan-area-level home prices has a very strong effect on defaults, with homes in areas with stronger past price growth (or smaller declines) defaulting much less frequently. Turning to the set of borrower and loan characteristics, we find a strong negative association between FICO score at mortgage origination and subsequent loan performance. We also find that higher default rates are associated with greater leverage on the first-lien loan at origination (loan-to-value ratios), lower borrower income, and higher loan amounts. We further document that nonamortizing mortgages, mortgages that combined short periods of fixed interest rates with adjustable rates thereafter (the so-called 2/28 and 3/27 hybrid 
Multivariate analysis of loan performance

\begin{tabular}{|c|c|c|}
\hline & $\begin{array}{l}\text { Default in the } \\
\text { first } 12 \text { months }\end{array}$ & $\begin{array}{l}\text { Default in the } \\
\text { first } 24 \text { months }\end{array}$ \\
\hline rear or Ongmátion & & \\
\hline Builder-affiliate indicator & $\begin{array}{l}-0.74 \\
(-10.0)^{\star \star}\end{array}$ & $\begin{array}{l}-1.24 \\
(-2.4)^{\star}\end{array}$ \\
\hline Change in market interest rate since origination & $\begin{array}{c}0.63 \\
(11.7)^{\star \star}\end{array}$ & $\begin{array}{c}2.48 \\
(15.2)^{\star \star}\end{array}$ \\
\hline MSA home price growth since origination & $\begin{array}{l}-6.19 \\
(-4.2)^{\star *}\end{array}$ & $\begin{array}{l}-12.43 \\
(-7.5)^{\star \star}\end{array}$ \\
\hline Change in MSA unemployment rate since origination & $\begin{array}{l}-0.45 \\
(-4.2)^{\star *}\end{array}$ & $\begin{array}{l}-0.89 \\
(-7.0)^{* *}\end{array}$ \\
\hline FICO score at origination & $\begin{array}{l}-0.02 \\
(-36.9)^{\star \star}\end{array}$ & $\begin{array}{l}-0.04 \\
(-45.1)^{\star \star}\end{array}$ \\
\hline Loan-to-value ratio at origination & $\begin{array}{c}0.04 \\
(28.2)^{* *}\end{array}$ & $\begin{array}{c}0.11 \\
(19.3)^{* *}\end{array}$ \\
\hline Log income (\$1,000s) & $\begin{array}{l}-0.52 \\
(-4.8)^{\star \star}\end{array}$ & $\begin{array}{l}-1.06 \\
(-5.5)^{\star *}\end{array}$ \\
\hline Not primary occupancy & $\begin{array}{l}0.37 \\
(1.6)\end{array}$ & $\begin{array}{l}0.16 \\
(0.3)\end{array}$ \\
\hline Log loan amount & $\begin{array}{l}0.71 \\
(5.6)^{\star \star}\end{array}$ & $\begin{array}{l}0.89 \\
(2.9)^{\star *}\end{array}$ \\
\hline First observed interest rate & $\begin{array}{c}0.63 \\
(24.4)^{\star \star}\end{array}$ & $\begin{array}{c}1.16 \\
(13.9)^{\star \star}\end{array}$ \\
\hline Non-amortizing mortgage & $\begin{array}{c}1.00 \\
(16.0)^{\star \star}\end{array}$ & $\begin{array}{c}2.51 \\
(23.0)^{\star \star}\end{array}$ \\
\hline Amortizing adjustable-rate mortgage, non-hybrid & $\begin{array}{c}-0.17 \\
(-1.8)\end{array}$ & $\begin{array}{l}-0.70 \\
(-2.8)^{\star *}\end{array}$ \\
\hline Amortizing adjustable-rate mortgage, hybrid & $\begin{array}{c}0.86 \\
(11.3)^{\star \star}\end{array}$ & $\begin{array}{l}2.14 \\
(8.8)^{\star \star}\end{array}$ \\
\hline Prepayment penalty & $\begin{array}{l}-0.08 \\
(-0.6)\end{array}$ & $\begin{array}{l}0.36 \\
(1.1)\end{array}$ \\
\hline Less-than-full documentation & $\begin{array}{c}0.32 \\
(12.4)^{\star *}\end{array}$ & $\begin{array}{l}0.67 \\
(7.8)^{\star \star}\end{array}$ \\
\hline Observations & $3,917,801$ & $3,917,801$ \\
\hline Pseudo R-squared & 0.279 & 0.320 \\
\hline Failure rate (percentage points) & 1.64 & 4.46 \\
\hline
\end{tabular}

Notes: MSA is metropolitan statistical area. Logit analysis, $1=90$ days or more past due within 12 (24) months. The sample includes purchase, conventional, first-lien mortgages for single-family homes. All regressions include state and year of origination fixed effects. The change in macrp variables is from the quarter of origination to the earliest of the following dates: first default, the last time the loan is observed in the sample, or four (eight) quarters following origination. The displayed coefficients represent marginal effects in percentage points. Z-statistics based on robus standard errors clustered at the state level are in parentheses; ${ }^{* *}$, * indicate significance at the 1 percent and 5 percent level, respectively. Sources: LPS Applied Analytics and authors' calculations.

adjustable-rate mortgages [ARMs]), and loans underwritten on the basis of incomplete documentation all defaulted at higher rates. The presence of these controls suggests that the estimated superior default performance of homebuilder loans derives from other factors. Before delving into a discussion of potential explanations, we test whether these results are present at different phases of the housing cycle.

\section{Change in homebuilder lending practices and mortgage performance}

We next split the sample into two subperiodsthe buildup to the housing bubble, covering the years 2001-04, and the peak years, followed by the housing price collapse (2005-08). If homebuilders were predisposed to aggressive lending, such tendencies would arguably be most pronounced in the latter period. In 2005-06, rapidly appreciating home prices may have 
led homebuilders to ramp up production and sales. In 2007-08, homebuilders found themselves with large excess inventories of unsold homes and may have been tempted to sell them to even marginally creditworthy borrowers.

Columns 3-6 of table 1 (p. 41) summarize dramatic changes in borrower and loan characteristics over these two periods for homebuilder-affiliated and other lenders. Of particular note is the finding that the share of homebuilder borrowers with low FICO scores (below 620) falls from 11 percent in 2001-04 to just 4 percent in 2005-08. A similar reduction (from 25 percent to 13 percent) is observed for borrowers with FICO scores below 660. Although this result can be partially explained by the drying up of securitization activity beginning in the second half of 2007, we note the absence of a decline in the share of low-FICO-score borrowers among other types of lenders. Indeed, during the $2005-08$ period, the share of affiliated lender loans going to low FICO borrowers was lower than the corresponding share for non-affiliated lenders.

However, homebuilders appeared to ratchet up the risk profile of their lending activities along a number of other dimensions during 2005-08. Their lending became even more concentrated in the bubble states; they appeared to be willing to finance houses at greater multiples to income, and they relied increasingly on exotic mortgage products, such as hybrid ARMs and non-amortizing mortgages. At the same time, they also shifted toward underwriting practices that allowed for incomplete income and asset documentation. All of these trends are either absent or less pronounced among other lenders.

In terms of unconditional 24-month default rates, homebuilder loans performed strictly better in the first half of the sample for both prime and subprime borrowers, as shown in columns 3 and 5 of table 1 (p. 41). However, in the later part of the sample, homebuilder loans have higher unconditional default rates. Although homebuilders cut back on their subprime exposure, their remaining subprime borrowers have higher default rates than subprime households borrowing from non-homebuilder lenders (27.4 percent versus 23.1 percent). Among prime borrowers, homebuilder loans showed even greater deterioration in relative default rates $(6.6$ percent versus 4.2 percent). The unconditional default rate during the late bubble period thus appears consistent with reckless homebuilder lending practices. Still, attributing higher defaults to underwriting practices requires, at a minimum, that we remove the potential influences of other default determinants.

To do that, we repeat the multivariate analysis described in the previous section for each of the two subperiods. The results, presented in table 3, are revealing. Even after conditioning on geographic and macroeconomic factors, as well as mortgage and borrower characteristics, homebuilder-affiliated mortgages originated during the early period (2001-04) exhibit lower default rates. This finding is true both for the short-horizon performance (column 1) and the longerhorizon performance (column 2). This result also suggests that the outperformance of homebuilder loans in the early period cannot be fully explained by the fact that homebuilders benefited from being particularly active in bubble states, where home prices increased the most.

If active participation in the boom areas was the only explanation for lower default rates of homebuilder loans during the formative years of the bubble, we would expect such loans to default more when home prices declined during the later period, as suggested by the comparison of unconditional default rates discussed above. In stark contrast, however, we find that conditional default rates on homebuilder loans are lower in the late bubble period (2005-08) over the short 12-month horizon (column 3). Over the 24-month horizon, the conditional default rates on homebuilder loans are statistically indistinguishable from those on non-homebuilder loans.

Put differently, homebuilder loans originated during the peak bubble years and in the dire aftermath of the housing collapse perform as well or better than their non-homebuilder counterparts issued in similar geographies to similar borrowers. This result is robust to sample choice, the definition of default, the set of covariates, and the type of econometric model. ${ }^{11}$

\section{Loan performance by contract type}

The results in table 3 highlight an intriguing contrast between the strength of relative outperformance of homebuilder loans originated in 2005-08 over the 12- and 24-month horizons. As noted earlier, during this period, homebuilders increasingly utilized mortgage contracts that did not require amortization in the early years of the loan. In our sample, such contracts accounted for 25 percent of homebuilder loans originated during 2005-08. ${ }^{12}$ The distinguishing characteristic of non-amortizing contracts is that they allow the borrower to make a lower payment initially compared with, say, a conventional fixed-rate amortizing mortgage. The ability to lower early payments is particularly pronounced in the case of the so-called negative amortization (or option ARM) contracts that allow payments to be less than the interest charges. Such lower payments, however, are only temporary, as all non-amortizing contracts have to begin paying down principal at some point. 
Multivariate analysis of loan performance, different subperiods

\begin{tabular}{|c|c|c|c|c|}
\hline \multirow[b]{2}{*}{ Year of origination } & \multicolumn{2}{|c|}{$\begin{array}{c}\text { Default in the } \\
\text { first } 12 \text { months }\end{array}$} & \multicolumn{2}{|c|}{$\begin{array}{c}\text { Default in the } \\
\text { first } 24 \text { months }\end{array}$} \\
\hline & 2001-04 & 2005-08 & 2001-04 & 2005-08 \\
\hline Builder-affiliate indicator & $\begin{array}{l}-0.48 \\
(-5.6)^{\star *}\end{array}$ & $\begin{array}{l}-0.71 \\
(-3.8)^{\star \star}\end{array}$ & $\begin{array}{l}-1.34 \\
(-6.0)^{\star *}\end{array}$ & $\begin{array}{l}0.40 \\
(1.0)\end{array}$ \\
\hline Change in market interest rate since origination & $\begin{array}{l}0.05 \\
(2.0)\end{array}$ & $\begin{array}{l}1.33 \\
(9.5)^{\star \star}\end{array}$ & $\begin{array}{c}-0.14 \\
(-1.4)\end{array}$ & $\begin{array}{c}4.67 \\
(12.9)^{\star \star}\end{array}$ \\
\hline MSA home price growth since origination & $\begin{array}{l}-9.07 \\
(-9.7)^{\star \star}\end{array}$ & $\begin{array}{l}-6.48 \\
(-2.3)^{\star}\end{array}$ & $\begin{array}{l}-12.64 \\
(-9.5)^{\star *}\end{array}$ & $\begin{array}{l}-12.47 \\
(-5.3)^{\star *}\end{array}$ \\
\hline Change in MSA unemployment rate since origination & $\begin{array}{l}0.03 \\
(0.6)\end{array}$ & $\begin{array}{l}-0.80 \\
(-4.4)^{\star \star}\end{array}$ & $\begin{array}{l}0.15 \\
(0.9)\end{array}$ & $\begin{array}{l}-1.34 \\
(-8.7)^{\star \star}\end{array}$ \\
\hline FICO score at origination & $\begin{array}{l}-0.01 \\
(-46.0)^{\star *}\end{array}$ & $\begin{array}{l}-0.03 \\
(-34.3)^{\star *}\end{array}$ & $\begin{array}{l}-0.02 \\
(-44.9)^{\star *}\end{array}$ & $\begin{array}{l}-0.07 \\
(-48.1)^{\star *}\end{array}$ \\
\hline Loan-to-value ratio at origination & $\begin{array}{c}0.02 \\
(17.6)^{\star *}\end{array}$ & $\begin{array}{c}0.06 \\
(16.0)^{\star *}\end{array}$ & $\begin{array}{l}0.04 \\
(22.4)^{\star *}\end{array}$ & $\begin{array}{l}0.18 \\
(11.6)^{\star *}\end{array}$ \\
\hline Log income $(\$ 1,000 s)$ & $\begin{array}{c}-0.29 \\
(-10.6)^{* *}\end{array}$ & $\begin{array}{l}-0.79 \\
(-4.0)^{\star *}\end{array}$ & $\begin{array}{l}-0.58 \\
(-10.6)^{\star *}\end{array}$ & $\begin{array}{l}-1.79 \\
(-5.0)^{* *}\end{array}$ \\
\hline Not primary occupancy & $\begin{array}{l}0.04 \\
(0.9)\end{array}$ & $\begin{array}{l}0.54 \\
(1.1)\end{array}$ & $\begin{array}{l}-0.59 \\
(-4.7)^{\star *}\end{array}$ & $\begin{array}{l}0.95 \\
(1.0)\end{array}$ \\
\hline Log loan amount & $\begin{array}{l}0.20 \\
(2.9)^{\star *}\end{array}$ & $\begin{array}{l}1.24 \\
(5.1)^{\star *}\end{array}$ & $\begin{array}{l}0.15 \\
(1.0)\end{array}$ & $\begin{array}{l}1.78 \\
(2.7)^{\star *}\end{array}$ \\
\hline First observed interest rate & $\begin{array}{c}0.13 \\
(11.4)^{\star \star}\end{array}$ & $\begin{array}{c}1.13 \\
(22.8)^{\star \star}\end{array}$ & $\begin{array}{c}0.25 \\
(10.0)^{\star *}\end{array}$ & $\begin{array}{l}1.96 \\
(8.7)^{\star \star}\end{array}$ \\
\hline Non-amortizing mortgage & $\begin{array}{l}0.33 \\
(6.8)^{\star \star}\end{array}$ & $\begin{array}{c}1.65 \\
(17.9)^{\star *}\end{array}$ & $\begin{array}{l}0.76 \\
(7.9)^{* *}\end{array}$ & $\begin{array}{l}3.91 \\
(24.4)^{* *}\end{array}$ \\
\hline Amortizing adjustable-rate mortgage, non-hybrid & $\begin{array}{l}-0.13 \\
(-4.2)^{\star \star}\end{array}$ & $\begin{array}{l}-0.03 \\
(-0.1)\end{array}$ & $\begin{array}{l}-0.38 \\
(-6.3)^{\star *}\end{array}$ & $\begin{array}{l}0.20 \\
(0.4)\end{array}$ \\
\hline Amortizing adjustable-rate mortgage, hybrid & $\begin{array}{l}0.15 \\
(4.8)^{\star *}\end{array}$ & $\begin{array}{l}1.47 \\
(8.2)^{\star \star}\end{array}$ & $\begin{array}{l}0.43 \\
(9.0)^{\star *}\end{array}$ & $\begin{array}{l}3.44 \\
(5.9)^{\star *}\end{array}$ \\
\hline Prepayment penalty & $\begin{array}{l}-0.01 \\
(-0.2)\end{array}$ & $\begin{array}{l}-0.11 \\
(-0.5)\end{array}$ & $\begin{array}{l}0.13 \\
(1.4)\end{array}$ & $\begin{array}{l}0.85 \\
(1.5)\end{array}$ \\
\hline Less-than-full documentation & $\begin{array}{l}0.15 \\
(5.3)^{\star *}\end{array}$ & $\begin{array}{l}0.38 \\
(8.3)^{\star *}\end{array}$ & $\begin{array}{l}0.13 \\
(1.9)\end{array}$ & $\begin{array}{l}1.01 \\
(7.8)^{\star *}\end{array}$ \\
\hline Observations & $1,946,958$ & $1,970,843$ & $1,946,958$ & $1,970,843$ \\
\hline Pseudo R-squared & 0.231 & 0.254 & 0.247 & 0.299 \\
\hline Failure rate & 0.513 & 2.74 & 1.43 & 7.45 \\
\hline \multicolumn{5}{|c|}{$\begin{array}{l}\text { Notes: MSA is metropolitan statistical area. Logit analysis, } 1=90 \text { days or more past due within } 12 \text { months. The sample includes purchase, } \\
\text { conventional, first-lien mortgages for single-family homes. All regressions include state and year of origination fixed effects. The change in macro } \\
\text { variables is from the quarter of origination to the earliest of the following dates: first default, the last time the loan is observed in the sample, or four } \\
\text { quarters following origination. The displayed coefficients represent marginal effects in percentage points. Z-statistics based on robust standard errors } \\
\text { clustered at the state level are in parentheses; }{ }^{* *},{ }^{*} \text { indicate significance at the } 1 \text { percent and } 5 \text { percent level, respectively. }\end{array}$} \\
\hline
\end{tabular}

The question that arises, therefore, is whether homebuilder loans originated during the bubble formation period did better in the short term because they were structured to make them easier to afford in the early years. In other words, can our results be ascribed to homebuilder-affiliated lenders' practice of designing loans that kicked potential problems down the road?

To get some insight into this possibility, we repeat the analysis of the previous section on subsamples defined by specific contract types. Although we used contract-type indicator variables in our preceding analysis, such controls are imperfect. Consequently, we use more flexible specifications that look separately at all non-amortizing contracts (interest-only or negative amortization) originated by homebuilder-affiliated and other lenders. We carry out a similar analysis on a subsample of conventional fixed-rate amortizing mortgages. 
TABLE 4

Multivariate analysis of loan performance by contract type

\begin{tabular}{|c|c|c|c|c|c|c|}
\hline \multirow[b]{2}{*}{ Year of origination } & \multicolumn{3}{|c|}{ Default in the first 12 months } & \multicolumn{3}{|c|}{ Default in the first 24 months } \\
\hline & 2001-08 & 2001-04 & $2005-08$ & 2001-08 & 2001-04 & 2005-08 \\
\hline \multicolumn{7}{|c|}{ Panel A. Non-amortizing mortgages only } \\
\hline Builder-affiliate indicator & $\begin{array}{l}-1.48 \\
(-9.8)^{\star \star}\end{array}$ & $\begin{array}{c}-0.52 \\
(-1.3)\end{array}$ & $\begin{array}{l}-1.86 \\
(-10.1)^{\star \star}\end{array}$ & $\begin{array}{l}0.69 \\
(1.0)\end{array}$ & $\begin{array}{l}-1.81 \\
(-2.6)^{\star *}\end{array}$ & $\begin{array}{l}1.52 \\
(1.8)\end{array}$ \\
\hline Macro, loan, and borrower controls & Yes & Yes & Yes & Yes & Yes & Yes \\
\hline Observations & 600,315 & 209,605 & 390,358 & 600,315 & 209,656 & 390,358 \\
\hline Pseudo R-squared & 0.234 & 0.296 & 0.200 & 0.282 & 0.288 & 0.245 \\
\hline Failure rate & 3.18 & 0.865 & 4.43 & 8.92 & 2.33 & 12.5 \\
\hline \multicolumn{7}{|c|}{ Panel B. Fixed-rate amortizing mortgages only } \\
\hline Builder-affiliate indicator & $\begin{array}{l}-0.50 \\
(-5.0)^{\star \star}\end{array}$ & $\begin{array}{l}-0.25 \\
(-3.4)^{\star *}\end{array}$ & $\begin{array}{l}-0.29 \\
(-2.6)^{\star \star}\end{array}$ & $\begin{array}{l}-0.80 \\
(-2.5)^{\star}\end{array}$ & $\begin{array}{l}-0.51 \\
(-2.9)^{\star \star}\end{array}$ & $\begin{array}{l}0.27 \\
(0.7)\end{array}$ \\
\hline Macro, loan, and borrower controls & Yes & Yes & Yes & Yes & Yes & Yes \\
\hline Observations & $2,807,941$ & $1,409,667$ & $1,398,274$ & $2,807,941$ & $1,409,667$ & $1,398,274$ \\
\hline Pseudo R-squared & 0.260 & 0.228 & 0.251 & 0.290 & 0.233 & 0.287 \\
\hline Failure rate & 0.96 & 0.404 & 1.52 & 2.88 & 1.19 & 4.59 \\
\hline
\end{tabular}

Notes: Logit analysis, $1=90$ days or more past due within 12 (24) months. The sample includes non-amortizing purchase, conventional, first-lien mortgages for single-family homes. All regressions include state and year of origination fixed effects, as well as the full set of covariates utilized in tables 2 and 3 . The displayed coefficients represent marginal effects in percentage points. Z-statistics based on robust standard errors clustered at the state level are in parentheses; ${ }^{*}$, ${ }^{*}$ indicate significance at the 1 percent and 5 percent level, respectively.

Sources: LPS Applied Analytics and authors' calculations.

The results are shown in table 4. Since the focus is on homebuilder-affiliated lenders, we do not show the coefficients on all of the other controls, although they are included in all of the regressions. Indeed, we find a telling contrast between the 12- and 24-month default rates among non-amortizing mortgages (table 4, panel A). Whereas homebuilder loans experienced lower 12-month default rates on mortgages originated during the 2005-08 period (column 3), their relative default rates became higher over the longer 24-month horizon (column 6). Although the latter result is only marginally statistically significant, it is consistent with the possibility that better performance of homebuilder loans is more illusory than real.

Why could the homebuilders have been interested in originating loans that make it easier to avoid default in their early years? Part of the answer may lie in homebuilders' reliance on securitization markets to fund their mortgages (Gartenberg, 2010). Under standard securitization agreements, an originator agrees to buy back from an investor any loan that defaults shortly (typically, within three or four months) after origination. Since homebuilder lenders had relatively little capital to accommodate such repurchase requests, they may have chosen to utilize non-amortizing mortgages as the means to manage this risk.
However, this does not imply that homebuilder default performance documented earlier in the article was driven exclusively (or even primarily) by such window-dressing practices. Panel B of table 4 shows that for fixed-rate amortizing mortgage contracts, which accounted for the lion's share of lending, homebuilder loans performed much better over the 12-month horizon for the entire period and each of the subsamples (columns 1-3). Over the 24-month horizon, their performance was better for the 2001-04 loan originations and effectively the same as that for non-homebuilder loans for the 2005-08 originations. These results are in line with our earlier analysis, while removing any potential contamination from improper controls for different mortgage contract composition.

\section{Discussion of results and directions for future work}

We find that relative to other lenders, homebuilders financed mortgages in riskier geographies and served borrowers with observably riskier characteristics during the 2001 to 2008 period. However, we also show that these mortgages defaulted at significantly lower rates over the total sample period, once we control for the confounding influences of time, location, and risk characteristics. The finding of similar or better default 
rates on homebuilder loans is particularly interesting for the 2005-08 origination period, when lending standards in mortgage markets were considered most lax and when the inventory of unsold houses was rising rapidly. While our study focuses on the performance of homebuilder loans and not on their building activity, the fact that these loans defaulted less than comparable loans by other lenders is inconsistent with explanations of the subprime mortgage crisis that envision a large role for homebuilders.

In addition, our findings cannot be easily reconciled with the existing literature on lending by affiliated firms. Like Carey, Post, and Sharpe (1998) and Barron, Chong, and Staten (2008), we find that homebuilder financing affiliates lend to riskier borrowers. However, unlike Barron, Chong, and Staten's (2008) study of auto loans, we find that homebuilder affiliate loans have lower rather than higher default rates.

What is it about homebuilder financing affiliates that might account for this difference? As is the case for other captive lenders, the corporate parent profits from both the loan and the sale of the primary good. In addition, the incentives for riskier underwriting grow stronger when inventory levels are high, as signaling and agency issues offset the benefits of knowledge and coordination gained with integrating lending and sales (Pierce, 2012).

Research on bank lending provides one possible explanation. For instance, Agarwal and Hauswald (2010) show that banks with greater access to "soft" information are more willing to take on problematic borrowers. Homebuilders can arguably produce "soft" information more easily than other lenders as they interact with borrowers frequently during the home buying process. These interactions have the potential to reveal borrower characteristics - such as punctuality, willingness to provide information, or ability to meet pre-construction financial obligations - that are not captured by broadly available measures of risk such as FICO scores and income characteristics. Having such information increases the ability of homebuilder lenders to avoid fraudulent transactions and make sound credit allocation decisions.

Stroebel (2013) offers a novel information-based channel to explain the superior performance of homebuilder-affiliated lenders. His paper emphasizes the informational advantages of affiliated lenders that manifest themselves not just through better ability to assess borrower creditworthiness, but also through better knowledge of the quality of housing construction. Better-built homes maintain higher collateral values and therefore represent a safer investment, holding borrower characteristics constant. Stroebel (2013) shows that houses financed by homebuilders indeed exhibited higher ex post appreciation rates and were less likely to experience major depreciation events, such as foundational cracks and leaky roofs. Moreover, this outperformance was greater among houses built on unstable (expansive) soil, where the quality of construction mattered most and where that quality could be best observed by the homebuilder.

Other aspects of the home buying process and the organization of homebuilders may help to explain the superior performance of homebuilder loans. Gartenberg (2010) emphasizes the role of organizational form and sources of financing in disciplining homebuilders. She shows that homebuilders employed lower-powered incentives than financial lenders, in order to balance competing internal goals (Holmstrom and Milgrom, 1991). Homebuilders also allocated limited capital to their lending units, forcing them to have little capacity to take back securitized loans, which further strengthened their incentives for careful underwriting (Gartenberg, 2010). As our results suggest, these incentives may also have contributed to greater utilization of non-amortizing mortgage contracts by homebuilder lenders, which have a particularly strong impact on short-term loan performance.

Two other aspects of buying new homes from a large corporate homebuilder merit discussion. The process of selecting a new home and its many features is often protracted and involves multiple interactions between the sales agent, prospective buyer, and eventually the loan underwriter. Although the credit decision is done separately from the sales process, homebuilder sales agents often engage in some form of financial education in their interactions with prospective buyers. They discuss topics such as typical maintenance expenses (for example, those covered or not covered by the homeowners association), relative cost-benefit trade-offs of different building features, and ability to generate rental income, among others. All of these discussions arguably allow prospective borrowers to form more-accurate forecasts of expenses associated with homeownership. Other research has found that financial education programs geared toward budgeting for homeownership, both from the standpoint of amassing a down payment and contingency funds for home maintenance, have a sizable positive effect on subsequent mortgage performance (Agarwal et al., 2010). Finally, the often considerable time lag between signing the original sales contract and taking final possession of a completed house implies a number of differences between buyers who pre-commit to purchasing a new home and the general home buyer population. New home buyers (the only kind that homebuilder lenders serve) are willing to wait longer to get into their new 
homes. They are also less likely to be liquidity-constrained, since they are able to tie up sizable purchase contract deposits for long periods. Again, these factors are likely to be positively associated with better mortgage performance.

These explanations have different implications for what policy should or can do. Should policy goals be centered on changing incentives for lenders? Would greater investment in financial education improve credit decisions and outcomes? Or, is it perhaps true that buyers of new homes simply represent a different population of borrowers and their experience cannot be translated to other types of borrowers? Similarly, part of the superior performance of homebuilder loans originated during the boom-and-bust years appears to have come from the utilization of contract types that made early defaults less likely. In those years, capital markets did not generally condition early pay defaults on contract type; this may no longer be the case in the future given the experience of the recent mortgage crisis. Understanding how homebuilders were able to lend to riskier borrowers, use riskier loan terms, be very active in risky locations, and still underwrite mortgages with lower default rates than other lenders is an important research goal and may provide useful insights for housing policy.

\section{NOTES}

${ }^{1}$ See figure 1 (p. 39) for a time series of new and existing home purchases and the fraction of new home purchases financed by homebuilders. During the housing boom years (2004-06), there was a gradual increase in the share of homebuilder-financed homes.

${ }^{2}$ Nine of the ten largest homebuilders have a financing affiliate. Among the ten largest homebuilders, the share of loans financed by an affiliate ranges from 57 percent for $\mathrm{KB}$ /Countrywide to 91 percent for Pulte.

${ }^{3}$ Like many other lenders, builder-affiliated lenders securitize most of their loans, so incentives arising from the ability to securitize are likely to be similar for them as for unaffiliated lenders that also securitize.

${ }^{4}$ See, for example, www.businessweek.com/stories/2007-08-12/ bonfire-of-the-builders.

${ }^{5}$ Two important exceptions are Gartenberg (2010) and Stroebel (2013), which are discussed in more detail later in this article.

${ }^{6}$ See www.hopenow.com for additional details on activities of the Alliance.

${ }^{7}$ Our results are fully robust to including FHA and VA mortgages in the sample.
${ }^{8}$ We define a loan as being in default if it is 90 days or more past due, in foreclosure, or is real-estate owned in the first 12 (or 24) months after the first mortgage payment date.

${ }^{9} \mathrm{~A}$ county-level correlation between the share of homebuilderoriginated loans in 2005 (depicted in figure 2, p. 42) and 12-month default rates on loans originated in 2005 (depicted in figure 4 , p. 44$)$ is -0.02 .

${ }^{10} \mathrm{We}$ also estimate ordinary least squares (OLS) and Cox proportional hazard models, which produce qualitatively similar results.

${ }^{11}$ Gartenberg (2010) obtains similar results in a sample of newconstruction homes in the top 100 zip codes by building activity, using a Cox proportional hazard model of defaults. For the logit, OLS, and hazard models based on the data in this article, we evaluated both the 12- and 24-month default rates. These results are available on request.

${ }^{12}$ The majority ( 88 percent) of non-amortizing loans originated by homebuilder-affiliated lenders during this period were interestonly loans. The rest were negative amortization loans that allow mortgage balances to grow over time. 


\section{REFERENCES}

Agarwal, Sumit, Gene Amromin, Itzhak Ben-David, Souphala Chomsisengphet, and Douglas D. Evanoff, 2010, "Learning to cope: Voluntary financial education and loan performance during a housing crisis," American Economic Review, Vol. 100, No. 2, May, pp. 495-500.

Agarwal, Sumit, and Robert Hauswald, 2010, "Distance and private information in lending," Review of Financial Studies, Vol. 23, No. 7, July, pp. 2757-2788.

Barron, John M., Byung-Uk Chong, and Michael E. Staten, 2008, "Emergence of captive finance companies and risk segmentation in loan markets: Theory and evidence," Journal of Money, Credit and Banking, Vol. 40, No. 1, February, pp. 173-192.

Carey, Mark, Mitch Post, and Steven A. Sharpe, 1998, "Does corporate lending by banks and finance companies differ? Evidence on specialization in private debt contracting," Journal of Finance, Vol. 53, No. 3, June, pp. 845-878.

Degryse, Hans, and Steven Ongena, 2005, "Distance, lending relationships, and competition," Journal of Finance, Vol. 60, No. 1, February, pp. 231-266.

Der Hovanesian, Mara, 2007, "Bonfire of the builders," BusinessWeek, August 13.
Gartenberg, Claudine, 2010, “Tempted by scope? Homebuilder mortgage affiliates, lending quality and the housing crisis," Harvard Business School, unpublished paper.

Holmstrom, Bengt, and Paul Milgrom, 1991, "Multitask principal-agent analyses: Incentive contracts, asset ownership, and job design," Journal of Law, Economics, \& Organization, Vol. 7, Special Issue, January, pp. 24-52.

Jiang, Wei, Ashlyn Aiko Nelson, and Edward Vytlacil, 2013, "Liar's loan? Effects of origination channel and information falsification on mortgage delinquency," Review of Financial Studies, forthcoming.

Pierce, Lamar, 2012, “Organizational structure and the limits of knowledge sharing: Incentive conflict and agency in car leasing," Management Science, Vol. 58, No. 6, June, pp. 1106-1121.

Stroebel, Johannes, 2013, "The impact of asymmetric information about collateral values in mortgage lending," New York University, Leonard N. Stern School of Business, working paper. 